\title{
EXAMINATION OF PULMONARY TUBERCULOSIS PATIENTS AT THE REGIONAL GENERAL HOSPITAL (RSUD) JAYAPURA
}

\author{
Herlando Sinaga ${ }^{a^{*}}$ \\ a Department of Health Analyst ; Universitas Sains dan Teknologi Jayapura \\ Sentani-Padang Bulan ; Abepura ; Jayapura ; Papua 99351 ; Indonesia
}

\begin{abstract}
Tuberculosis is a disease that is directly transmitted and caused by bacteria mycobacterium tuberculosis. Tuberculosis is an infectious disease that still causes high morbidity and mortality rates in the world. This research aims to determine the value of hemoglobin levels, platelet counts, erythrocytes, the number of neutrophils and monocytes in positive patients with pulmonary tuberculosis who performed examinations at the Jayapura Regional General Hospital. This research is descriptive with a laboratory test approach. The population in this research included all patients who had positive pulmonary tuberculosis and the samples in this study were venous blood positive patients with pulmonary tuberculosis. The method used in this examination is flow cytometry using the hematology analyzer Sysmex XN-1000. The results of the research showed that from 20 samples, hemoglobin levels were obtained as much as $30 \%$ with normal hemoglobin levels and as much as 70\% with low hemoglobin levels $70 \%$ of normal platelet value and as much as $30 \%$ high platelet count; $70 \%$ of the value of erythrocytes is normal and as much as $30 \%$ the amount of erythrocytes decreases; neutrophils are as high as $55 \%$ while normal is $45 \%$; and high monocytes as much as $25 \%$ and normal monocytes as much as $75 \%$.
\end{abstract}

Keywords: patients TB ; hemoglobin ; platelets ; erythrocytes ; neutrophils ; monocytes

\section{Introduction}

Tuberculosis is a chronic infectious disease caused by mycobacterium tuberculosis. These bacteria are rod-shaped and are acid-resistant so we know them as Basil Acid Resistant (BTA). Most of the bacteria mycobacterium tuberculosis often attacks the pulmonary parenchyma and causes it pulmonary tuberculosis, besides that it can also attack other body organs (extrapulmonary tuberculosis) such as the pleura, lymph glands, bones, and other extra lung organs and this disease is easily transmitted and infects all ages (Depkes, 2013).

Based on data, there was a 9.6 million world population infected with pulmonary tuberculosis in 2014. The highest number of cases of Pulmonary tuberculosis was in the African

*) Corresponding Author (Herlando Sinaga)

E-mail: herlandosinaga03@gmail.com region of $37 \%$, Southeast Asia region $28 \%$ and the Eastern Mediterranean region 17\% (WHO, 2015). In Indonesia, the prevalence of pulmonary tuberculosis is grouped into three regions: Sumatra (33\%), Java and Bali (23\%), and Eastern Indonesia (44\%) (the Republic of Indonesia, 2014). Based on the health profile of Papua Province, the discovery of new cases of pulmonary tuberculosis in Papua Province in 2013 was 2,778 people, in 2014 there were 2,111 people, in 2015 there were 2,555 people and in 2016 there were 2,050 people (Papua Provincial Health Office, 2017).

Hematological examination in pulmonary tuberculosis patients in 2015 was obtained, namely: Hemoglobin levels which ranged from 8.1-16.5 g/dL and those with anemia ranged from $65 \%$; Hematocrit levels ranged from 26.8 to $44 \%$ (hemodilution $36.1 \%$ and normal HT $63.9 \%$ ); The sedimentation rate of blood has an increase 
in LED values ranging from $15-145 \mathrm{~mm} /$ hour with a percentage of $98.6 \%$; Platelet counts range from $\quad 68.000-882.000 \quad$ cell $/ \mathrm{mm} 3 \quad(51 \%$ thrombocytosis, 3\% thrombocytopenia and normal platelets $46 \%$ ); The number of leukocytes obtained ranges from 1.000-18.400sel/mm3 (3\% leukopenia, $45 \%$ leukocytosis and 52\% normal leukocytes); MCV ranges from 57.9-90.5 33 ; $\mathrm{MCH}$ ranges from 17-32uug and $\mathrm{MCHC}$ ranges from 30.7 to $35.7 \mathrm{~g} / \mathrm{dL}$ (Sundari et al., 2017).

One investigation supporting the diagnosis of pulmonary tuberculosis infection is hematological examination including hemoglobin, platelets, erythrocytes, neutrophils, and monocytes. Decrease in hemoglobin levels is a major feature in patients with bacterial infections, especially infections lasting over one month including pulmonary tuberculosis where the bacteria is passed through the blood so that the erythropoiesis process occurs because body tissues do not get enough oxygen because hemoglobin has an important role in spreading oxygen from the lungs throughout the body is disrupted and damaged by cell tissue (Lasut et al., 2016).

Anti-Tuberculosis drugs (OAT) still hurt patients, including the effects of hemorrhage, which can cause anemia, thrombocytopenia and affect the sedimentation rate of the patient's blood. Anemia in tuberculosis can occur due to interference with the process of erythropoiesis by inflammatory mediators, shortening the life span of erythrocytes, iron metabolic disorders, the presence of malabsorption and insufficient nutrients due to low appetite. Some studies show that anemia of chronic diseases is more common in people with tuberculosis compared to iron deficiency anemia. Decreased deficiency anemia can be characterized by iron deposits, decreased serum ferritin, decreased serum iron accompanied by increased serum transferring, decreased Mean Corpuscular Volume (MCV) and decreased hemoglobin levels (Purnasari, 2011). Anemia can also be caused due to bleeding in the lungs due to mycobacterium tuberculosis infection (Miyata, 2013).

Thrombocytopenia in tuberculosis occurs due to complications from therapy, Rifampin has been known to cause thrombocytopenia. Thrombocytopenia can also be caused due to a pre-existing tuberculosis infection or hematological disorder (Oehadian, 2013).

The increase in neutrophils in the blood results indicates that the body, which is white blood cells, is fighting infections that invade the body and continue to eat the production of germs and also foreign objects in the body, like bacteria (Kane, 2017).

Monocytes function as macrophage cells that will function for the immune system. Monocytes will destroy these foreign objects in the body, destroy abnormal cells such as cancer cells, and also remove body tissue that has been damaged or dead (Kane, 2014).

Jayapura Regional Hospital was used as a research site because there were still a lot of pulmonary tuberculosis patients in Jayapura and Jayapura Hospital in 2011, there were 329 patients with pulmonary tuberculosis.

\section{Method}

This type of research is descriptive with a laboratory test approach. The research was conducted at the Jayapura Regional General Hospital. The population in this study were all patients who had positive pulmonary tuberculosis and conducted a health examination in Jayapura Public Hospital, the sample in this study was venous blood positive patients with pulmonary tuberculosis. The method to be used in this examination is flowcytometry using the hematology analyzer Sysmex XN-1000.

The results obtained will be compared with the interpretation of the post-analytical results of the examination to get the normal, low and high ranges. Some interpretation of the results of the examination, Sysmex (2013) include:

a. Post-analytic hemoglobin is as follows:

Men: 13.3-16.6 gram/dL or g\%

Women: 11.0-14.7 grams/dL or $\mathrm{g} \%$

b. Post-analytical Platelet Counts are:

Men and women: 150,000 - 400,000 cells/mm3

c. Post-analytical Erythrocyte Amount is:

Men: 4.5 - 6.5 million cells / $\mathrm{mm} 3$

Women: 4.0 -5.5 million cells / mm3

d. Post-analytic neutrophil value:

Men and women 39.8\% - -70.5\%

e. Post-analytic monocytic value:

Men and women $4.3 \%-10.0 \%$

\section{Result and Discussion}

In this study for 1 month, a sample of 20 pulmonary TB patients was obtained. Presentation of data is done in the form of tables as follows : 
Table 1. Data on Hemoglobin Examination, Thrombocyte Amount, Erythrocyte Amount, Neutrophils and Monocytes in Tuberculosis Patients at the Jayapura Regional General Hospital.

\begin{tabular}{lcccc}
\hline Parameter & $\begin{array}{c}\text { Number } \\
\text { of } \\
\text { Samples }\end{array}$ & $\begin{array}{c}\text { Normal } \\
(\%)\end{array}$ & $\begin{array}{c}\text { Results } \\
(\%)\end{array}$ & $\begin{array}{c}\text { High } \\
(\%)\end{array}$ \\
\hline $\begin{array}{l}\text { Hemoglobin } \\
\text { Platelet }\end{array}$ & 20 & $6(30 \%)$ & $14(70 \%)$ & - \\
Counts & 20 & $14(70 \%)$ & - & $6(30 \%)$ \\
Erythrocyte & 20 & $14(70 \%)$ & $6(30 \%)$ & - \\
Neutrophil & 20 & $9(45 \%)$ & - & $11(55 \%)$ \\
Monocytic & 20 & $15(75 \%)$ & - & $5(25 \%)$ \\
\hline
\end{tabular}

The data in Table 1 shows the number of samples as many as 20 samples which have different results at each examination, among others: Hemoglobin examination obtained normal results of 6 samples (30\%), low as many as 14 samples $(70 \%)$; normal platelet examination of 14 samples (70\%) and high as many as 6 samples (30\%); erythrocyte examination obtained normal results of 14 samples (70\%) and low as many as 6 samples (30\%); examination of neutrophils has a normal result of 9 samples (45\%) and high yields of 11 samples (55\%); and monocyte examination showed normal results of 15 samples $(75 \%)$, then there were 5 samples high $(25 \%)$.

The difference in the results of the examination showed abnormalities or changes in the hematology of pulmonary TB patients, which based on table 1 showed that from 20 samples that were examined for hemoglobin the results were 6 samples $(30 \%)$ with normal hemoglobin levels and 14 samples (70\%) with levels low hemoglobin with an average level of 9,905 grams/dL. This is caused by inflammatory mediators, namely the bacterium mycobacterium tuberculosis. This is consistent with the results of a study conducted by Lasut, et al. (2016), which states that a decrease in hemoglobin levels is caused by inflammatory mediators which is the most common pathogenesis of anemia and low hemoglobin in pulmonary tuberculosis. A decrease in hemoglobin is also caused because the body's tissues will not get enough oxygen.

According to Weiss (2005), anemia caused by chronic infections such as pulmonary tuberculosis has the characteristic of disrupting iron homeostasis with increased capture and iron retention in RES cells. Iron is the most important growth factor for mycobacterium tuberculosis. Iron retention in the reticuloendothelial system is one of the body's defense mechanisms. The disturbance of hemostatic iron causes the transfer of iron from the circulation to the reticuloendotinal system storage and is followed by a limited supply of iron for erythroid progenitor cells, which causes limited erythrocyte formation.

Decreased hemoglobin levels often occur in patients with pulmonary tuberculosis because of the suppression of erythropoiesis by inflammatory mediators. According to Nasution (2015), state suppression by inflammatory mediators is the most common pathogenesis of anemia in pulmonary tuberculosis. This condition occurs because of the dysregulation of the immune system associated with a systemic response to the condition of the disease suffered. Increases in proinflammatory cytokines such as TNF- $\alpha$, IL-6, IL-1 $\beta$, and interferon- $\gamma$ affect decreasing erythroid progenitor inhibits direct differentiation and proliferation of erythrocytes. In addition to the main factors mentioned above,several general factorscan affect hemoglobin levels including diet, nutritional status, excessive activity, consuming alcoholic beverages, taking drugs, iron sufficiency in the body and metabolism in the body. According to Hayati (2011), normal hemoglobin levels in patients with pulmonary tuberculosis can be influenced by several interrelated factors including the duration of therapy for pulmonary tuberculosis (OAT), the degree of severity of pulmonary tuberculosis and high iron diet.

Therapy for pulmonary tuberculosis drugs (OAT) in patients with positive pulmonary tuberculosis at the end of treatment, namely in months 4 to 6 experienced an increase in hemoglobin so that the low hemoglobin level at the beginning of treatment became normal. The treatment of months 4 to 6 aims to prevent the recurrence of chronic diseases due to inflammation caused by $M$. tuberculosis infection. The degree of severity of pulmonary tuberculosis is very influential on hemoglobin levels in patients with positive pulmonary tuberculosis wherein the scanty category and 1+ the hemoglobin level tends to increase until it becomes normal which initially has decreased hemoglobin levels. In this category, the number of $\mathrm{M}$. tuberculosis bacteria is smaller so that the inflammatory process is not like category $2+$ and $3+$ which when referenced to the interpretation of IUALTD results more bacteria infect patients with positive pulmonary tuberculosis. Foods that 
contain lots of iron are food ingredients derived from animal meat. Iron is also essential in producing hemoglobin which functions to deliver oxygen from the lungs to body tissues and iron plays a role in the synthesis of hemoglobin in red blood cells and myoglobin in muscle cells. Therefore a diet with high iron is very influential on the hemoglobin level of pulmonary tuberculosis patients who have decreased hemoglobin levels so that it can be increased to normal hemoglobin levels through a diet with high iron.

Based on Table 1, the platelet examination results that were normal were 14 samples $(70 \%)$ and 6 samples (30\%) high. High platelet counts can generally be caused by excessive reactions in the body by several conditions, such as allergies, heart attacks, physical exercise, iron deficiency, vitamin deficiencies, and infections (tuberculosis). This reaction triggers the release of cytokines, which causes increased platelet production. Based on research conducted by Fhatana et al., Thrombocytosis was found as much as $25.6 \%$, thrombocytosis is a response to inflammation where this inflammatory response causes the production of platelet stimulating factors that play a role in stimulating the release of platelets from the bone marrow in line with blood circulation. Besides thrombocytosis can be a response to the occurrence of acute bleeding, wherein patients with tuberculosis bleeding that often occurs is Hemoptysis.

Hemoptysis or coughing up blood is a health problem that has the potential to cause death because it is difficult to predict the severity and clinical development (Wibisono, 2010). Hemoptysis in large numbers (massive) includes medical emergencies that must get intensive treatment with appropriate therapy. Besides being able to interfere with hemodynamic stability due to large amounts of blood loss, massive hemoptysis can also disrupt gas exchange in the alveoli and cause complications of asphyxia with high mortality rates. Research from Irfa (2014) who conducted research in the pulmonary ward of Dr. RSUP M. Djamil Padang found that the mortality rate of patients with hemoptysis in the period January 2011 December 2012 was $6.8 \%$ of the total incidence of hemoptysis and the incidence of hemoptysis based on the disease underlying the hemoptysis in patients was mostly caused by pulmonary TB. Table 1 also shows the results of erythrocyte examination in pulmonary TB patients, where the normal results were 14 samples $(70 \%)$ and low as many as 6 samples (30\%). The low value of erythrocytes is caused by the presence of $\mathrm{M}$. tuberculosis infection. According to Purnasari (2011), anemia in tuberculosis is caused by bleeding in the lungs due to infection with $\mathrm{M}$. tuberculosis bacteria. Irregular erythrocytes are also caused by the process of erythropoiesis (destruction of erythrocytes) by inflammatory mediators or damage to blood cells and insufficient nutrients due to low appetite.

Anemia can also be caused by side effects of anti-tuberculosis drugs, such as Isoniazid and rifampicin. Based on the results of research conducted by Farazi et al. (2014) as many as $14.7 \%$ of patients who received anti-tuberculosis drug therapy experienced hematological disorders due to the side effects of the anti-tuberculosis drug. The same thing happened in the study of Kassa et al (2016) which showed a decrease in the average hemoglobin level of 12.7 $\mathrm{g} / \mathrm{dL}$ before getting OAT therapy to $11.8 \mathrm{~g} / \mathrm{dL}$ after getting OAT therapy, and a decrease in the average value hematocrit from $38.5 \%$ before getting OAT therapy to $35.7 \%$ after getting OAT therapy. This shows that the side effects of OAT can cause tuberculosis patients to become anemic.

Based on Table 1, in pulmonary tuberculosis patients from 20 samples obtained high neutrophil values of 11 samples $(55 \%)$ and 9 samples $(45 \%)$ had normal neutrophil values. This high neutrophil value is caused because Neutrophils are directly related to the body's defense against bacterial infections and other small inflammatory processes. Neutrophils usually also provide the first response to bacterial infections, judging from the activity and the dearth of large numbers of neutrophils. Neutrophils circulate in the bloodstream and will react when there is an infection, both from viruses, bacteria, etc. According to Wirawan (2011), neutrophils migrate to the site of infection to start killing the invading microbes by phagocytosis into the intracellular pouch, the phagosome. Then a metabolic process occurs in the granules to produce hydrogen that destroys ingested bacteria. Neutrophil granules are a microscopic package of powerful enzymes capable of digesting various types of cellular materials.

The results of the study in Table 1 show the value of monocytes in pulmonary tuberculosis patients, there is a high monocyte in 5 samples $(25 \%)$ of 20 samples. The high number of Monocytes in the body is caused by the 
resistance of Monocytes to $\mathrm{M}$. Tuberculosis and destroying damaged cells and repairing damaged tissue. The increase in the number of monocytes can occur because monocyte cells play an important role in the immune response in TB infections so that when these bacteria cause TB to enter the body, monocytes multiply to phagocytize them. In addition to tuberculosis diseases that can increase the number of monocytes are measles, mumps, mononuclear, parasite infection, leukemia, lupus, and vasculitis. According to Oehadin (2003), M. tuberculosis bacteria that cause $\mathrm{TB}$ have phospholipids in their cells, so that some phospholipids from M. tuberculosis are degraded by monocytes and macrophages in the tissues that cause the transformation of these cells into epithelioid cells. Monocytes are the main cells in tubercle formation. Activation of this tubercle formation can be described by monocytosis in the blood.

The height of monocytes and neutrophils can be caused by the activity of monocytes and neutrophils in the face of infection, a disruption of the immune system, drugs that make the number of neutrophils and monocytes, and the disruption of the bone marrow which causes abnormal production of neutrophils and monocytes. Symptoms of increased neutrophils and monocytes can be recognized by the presence of fever, bleeding or bruising, weak body terrace, fainting, arms, legs, and stomach aching or tingling, and no appetite.

According to Khaironi et al. (2017), who conducted a study of Pulmonary Tuberculosis Patients Before Treatment with Intensive One-Month Treatment at Pekanbaru Health Center found that of the twelve samples examined overall showed a comparison between the number of leukocytes, lymphocytes, monocytes, and granulocytes in patients $\mathrm{TB}$ before treatment with intensive one-month treatment which showed an increase, decrease, and still within normal limits. The overall leukocyte count results from the study in TB patients before treatment exceeded the normal limit of $25 \%$ and after intensive one-month treatment exceeding the normal limit of $25 \%$. The increase in the number of leukocytes in TB patients shows that there is a large amount of leukocytes to fight TB-causing bacteria in the overall phagocytosis process.

The effect of pathogens on the number of neutrophils and monocytes is characterized by an increase in the number of neutrophils and monocytes. The number of neutrophils and monocytes is high because of the large number of pathogens in the body so that the body produces many neutrophils and monocytes to fight these pathogens. The process of neutrophils and monocytes in carrying pathogens begins with the body producing large numbers of neutrophils to kill the pathogen and the body produces large amounts of monocytes to help neutrophils and also cleanse dead neutrophils and also repair damaged tissue and cells. According to Kane (2017), the increase in neutrophil results indicates that the body is producing a lot of neutrophils to fight pathogens or foreign objects that enter the body, such as germs, the bacteria themselves. According to Kane (2014), monocytes in large quantities are a sign of ongoing infection in the body.

\section{Conclusion and Suggestion}

The conclusion of this study is that from 20 samples, hemoglobin levels were obtained as much as 30\% with normal hemoglobin levels and as much as $70 \%$ with low hemoglobin levels; $70 \%$ of normal platelet value and as much as $30 \%$ high platelet count; $70 \%$ of the value of erythrocytes is normal and as much as 30\% the amount of erythrocytes decreases; neutrophils are as high as $55 \%$ while normal is $45 \%$; and high monocytes as much as $25 \%$ and normal monocytes as much as $75 \%$.

The existence of a high or low value on the results of the examination shows an infection in the body of patients with pulmonary TB caused by $\mathrm{M}$. tuberculosis as well as showing evidence that the patient's body parts, especially blood and its components are carrying out resistance to M. tuberculosis.

Examination of pulmonary $\mathrm{TB}$ patients should be done regularly to determine the level of $\mathrm{M}$. tuberculosis infection in the patient's body and to determine the progress of the healing process of pulmonary TB disease.

\section{Acknowledgements}

Thank you to the Jayapura Regional General Hospital, which has helped a lot in the implementation of this research, as well as all parties involved in this research.

\section{References}

Departemen Kesehatan Republik Indonesia. (2013). Laporan Nasional Riset Kesehatan 
Dasar. Pusat Penelitian Pengembangan Kesehatan : Jakarta.

Departemen Kesehatan Republik Indonesia. (2014). Pedoman Penanggulan Nasional TBC. Departemen Kesehatan Republik Indonesia : Jakarta.

Farazi A, Sofian M, Jabbariasl M, \& Keshavarz S. (2014). Adverse reactions to antituberculosis drugs in Iranian tuberculosis patients. Hindawi Publishing Corporation.

Hayati, A. (2011). Evaluasi Kepatuhan Berobat Penderita Tuberculosis Paru Tahun 2010-2011 di Puskesmas Pancoran Mas Depok. Universitas Indonesia Press : Jakarta.

Irfa, Intan., IrvanMedison., DetyIryani. (2014). Gambaran Kejadian Hemoptisis pada Pasien di Bangsal Paru RSUP Dr. M. Djamil Padang Periode Januari 2011 Desember 2012. Jurnal Kesehatan Andalas 3(3), 397- 404.

Kane, Vincent, (2014). Monosit, Definisi Dan Fungsi

(Online)

http://www.kerjanya.net/faq/4809mono sit.html. diakses tanggal 01 Mei 2018.

Kane, Vincent, (2017). NeutrofilGranulosit, Definisi Dan Fungsi. (Online). http://www.kerjanya.net/faq/4761-neutr ofil-granulosit.html. diaksestanggal $1 \mathrm{Mei}$ 2018.

Kassa E, Enawgaw B, Gelaw A, \&Gelaw B. (2016). Effect of anti-tuberculosis drugs on hematological profiles of tuberculosis patients attending at University of Gondarn hospital, Northwest Ethiopia. BMC Hematology.

Khaironi, Syarifah. MellysaRahmita, dan RantiSiswani. (2017). Gambaran Jumlah Leukosit Dan Jenis Leukosit Pada Pasien Tuberkulosis Paru Sebelum Pengobatan Dengan Setelah Pengobatan Satu Bulan Intensif Di Puskesmas Pekanbaru. Jurnal Analis Kesehatan Klinikal Sains. 5(2). 61-71.

Nasution, Sibuea. (2015). IlmuPenyakitDalam. Rineka Cipta : Jakarta.
Oehadin. (2003). Aspek Hematologi Tuberkulosis. Fakultas Kedokteran Universitas Padjajaran. Bandung.

Oehadin. (2009). Paduan Lengkap Ilmu Penyakit Dalam, Penerbit Diva Press, Yogyakarta.

Purnasari, Galih. (2011). Penelitian Tuberculosis di Fakultas Kedokteran Universitas Diponegoro. Universitas Diponegoro Press : Semarang.

Sundari, Rini. Ida Parwati, Johanes Cornelius Mose, Budi Setiabudiawan. (2017). Perbedaan Parameter Hematologi Pada penderita Tuberculosis Paru Terinfeksi mycobacterium tuberculosis Galur Beijing dengan Galur Non-Beijing. Jurnal Kedokteran Bandung. 49(1).35-41.

Lasut, Natahalin. Linda W. A. Rotty, Efata B. I. Polii. (2016). Gambaran Kadar Hemoglobin dan Trombosit Pada Pasien Tuberculosis Paru di RSUP Prof. Dr. Kandou Manado Periode Januari 2014-Desember 2014. Jurnal e-clinic. 4(1).

Miyata, S. Tanaka. (2013). The Prognostic Significance of Nutritional Status Using Malnutrition Universal Screening Tool in Patients With Pulmonary Tuberculosis. Nutrition Journal, 12(1).

Papua Provincial Health Office. (2017). Profil Kesehatan Provinsi Papua. Dinas Kesehatan Provinsi Papua Press : Jayapura.

Sysmex Manual Book. (2013). Hematology Analizer. PT Saba Indonesia : Jakarta.

Weiss G, Goodnough LT. (2005). Anemia of Chronic Disease. $N$ Engl $J$ Med. 352(10):1011-23.

World Health Organization. (2015). Global Tuberculosis Report. WHO Press:Jenewa.

Wibisono MJ, Alsagaff H. Batukdarah. Dalam: Wibisono MJ, Winariani, Hariadi S editor (penyunting). Buku Ajar Ilmu Penyakit Paru (2010). Surabaya: Departemen Ilmu Penyakit Paru FK UNAIR-RSUD Dr. Soetomo; 2010. hlm. 74-87.

Wirawan, R. (2011). Pemeriksaan Laboratorium Hematologi. Badan Penerbit FKUI. Jakarta. 